\title{
Perceptions of Local Tourists, Attitudes and Willingness to Visit Local Destinations: A Destination Image Case
}

\author{
Kamantha Govender ${ }^{1}$, Eugine Tafadzwa Maziriri², Tinashe Chuchu $^{3}$ \\ Marketing Division, University of the Witwatersrand ${ }^{1,3}$ \\ Department of Business Management, University of the Free State ${ }^{2}$ \\ Correspondence email: MaziririET@ufs.ac.za ${ }^{2}$ \\ Received: 9 May 2021 Reviewed: 3 Jul2021 Accepted: 23 Aug 2021 Published: 31 Oct 2021
}

\begin{abstract}
The paper made use of predictor variables to highlight relationships in tourism, these are: perceptions of local residents towards tourists and destination image; to identify how these predictors are relative to the mediator variable, attitudes of local residents towards tourists; which then led to the outcome variable, tourist's willingness to visit a destination. Respondents were selected by means of non-probability sampling. A conceptualised model was developed to measure the variables adapted to the research study. The researcher conducted field research at The University of Witwatersrand, which included 270 respondents, currently registered at the university. The data set was analysed by employing SPSS and Amos 24 through Structural Equation Modelling (SEM). The results of the research confirmed that the attitudes of local residents had a stronger relationship than the perceptions of local residents towards tourists; influencing tourists' willingness to visit a destination. This implies that tourists will visit a destination based on how they are treated by local residents, instead of how local residents perceive tourists.
\end{abstract}

Keywords: attitudes, perceptions, tourists, destination image.

\section{A. INTRODUCTION}

Local residents' attitudes towards domestic tourism have been researched for over 30 years (García, Vázquez \& Macías, 2015; Jafari, 1986). Tourism's interactions with local communities creates economic, social and environmental impact for those communities (Martin, 2019). According to Brida, Osti \& Faccioli (2011), tourism is an exchange process, involving a direct and reciprocal relationship between users and producers of the tourism product which then describes the "tourism experience". Therefore, comprehension of local residents' attitudes toward tourism development is vital for the success and sustainability of any type of tourism development (Gursoy, Chi, \& Dyer, 2010). Many communities encourage the development of tourism to improve the quality of life for residents (Jurowski \& Gursoy, 2004). This confirms the suggestion from Jurowski \& Gursoy (2004) that research on residents continues to be a topic of interest to scholars. Understanding local tourists' attitudes allows for adopting an adequate responsive mechanism to the negative influences that arise from the 
tourism exchange (Williams \& Lawson, 2001; Sharma \& Dyer, 2009). Gursoy et al. (2010) established that a continued assessment of locals' perceptions of impacts, and their support level for different types of development may be necessary to ensure sustainability of industry and to manage the more critical aspects that appear as a tourism destination develops.

There is a need to understand the importance of local tourists and their contribution towards domestic tourism. Therefore, this creates the need for researchers and practitioners alike to investigate local tourist's attitudes and perceptions towards consuming tourism products at home. A community that plans and uses tourism as an alternative means of strengthening its economic development must develop sustainable tourism to meet the needs and demands of its residents (Puczkó \& Rátz, 2000). The purpose of this paper is to examine the willingness of locals to consider domestic tourism, their attitudes and perceptions towards practising tourism locally. Therefore, the chief research objective of this study is to empirically investigate the extent to which residents would be willing to visit local tourist attractions. The development of sustainable tourism is difficult without the support and participation of the community residents (Fallon \& Kriwoken, 2003; Gursoy \& Rutherford, 2004; Nicholas, Thapa $\&$ Ko, 2009). Prior empirical research on the importance of local tourists' has been conducted by Teye, Sirakaya \& Sönmez (2002) who examined the attitudes of residents of two towns towards the development of tourism. This study, therefore partly formed the basis of the present research. Additionally, authors such as Fallon \& Kriwoken (2003), Gursoy \& Rutherford (2004), Nicholas, Thapa \& Ko (2009) have posited that successful development of tourism greatly relies on the support and active participation of local residents of the particular community concerned. Local residents' support for tourism development is critical as successful operation and sustainability of tourism depends heavily on their goodwill (Jurowski, $\&$ Gursoy, 2004). This research follows the general theme of investigating domestic tourism covered by the works of Bryden (1973), de Kadt (1979), Lea (1988) \& Harrison (1992). However, the present research further examines residents' willingness to visit local tourist attractions, attitudes and perceptions towards domestic tourism. According to Teye et al. (2002), there is a dearth of research examining how the local resident's support and involvement impact tourism development efforts. Ramkissoon \& Nunkoo (2011) explain that not much focus has been placed on the attitudes and perceptions that local residents have relative to a place and how this influences the residents' support for tourism development.

The present research was quantitative involving using a survey instrument to collect data from 270 willing participants at a busy social centre. Due to the absence of a known-population 
size and sampling frame, convenience sampling, a non-probability sampling technique was adopted to select suitable participants. Justification for this sampling approach was based on Malhotra (2007) and Babin \& Zikmund (2015), who suggested using past similar studies to determine the most appropriate sample size. The present study was founded on the destination image theory explored in greater detail later in the paper. A limited number of studies have the image that residents hold of their surroundings. Even fewer have investigated the influence of those surroundings on their attitudes and reaction to tourism development (Stylidis, Biran, Sit $\&$ Szivas, 2014). Therefore, the abovementioned research inspires the need for more research work on local residents' attitudes towards domestic tourism. It is believed that this study contributes to existing comprehension of the effect that attitudes of local residents have towards their willingness to visit a destination. However, it was established that the local residents' attitudes significantly influenced their decisions to visit a local tourist attraction. The next section of this paper provides the theoretical framework for the study. A review of relevant literature is provided followed by the methodology adopted for the research. In conclusion, the findings, implications and suggestions for future research are discussed.

\section{B. LITERATURE REVIEW}

\section{Theory of Reasoned Action}

The theory of reasoned action has been widely used as a model for predicting behavioural intentions and behaviour (Ajzen \& Fishbein 1980; Madden, Ellen \& Ajzen, 1992). Sheppard, Hartwick \& Warshaw (1988) and Madden et al. (1992) noted that the model predicts behavioural intentions and behaviour quite well and is helpful in identifying where and how to target strategies for changing behaviour. The development and testing of the theory of reasoned action were predicated on the assumption that the behaviours being studied were under full volitional control (Madden et al. 1992). Ajzen (1991) states that volitional control is when an individual can decide at will to perform or not perform the behaviour. The theory of reasoned action, Fishbein, Jaccard, Davidson, Ajzen \& Loken (1980) posits that, behavioural intentions are a function of salient information or beliefs about the likelihood that performing a particular behaviour will lead to a specific outcome (Madden et al. 1992).

\section{Theory of Planned Behaviour}

An extension of the model proposed by Ajzen (1991), the theory of planned behaviour, incorporates perceived behavioural control as an ascendant to behavioural intentions (Madden et al. 1992). The theory of planned behaviour, Ajzen (1991) extends the boundary condition of 
pure volitional control specified by the theory of reasoned action. This is accomplished by including beliefs regarding the possession of requisite resources and opportunities for performing a specific behaviour. The more resources and opportunities individuals think they possess, the greater should be their perceived behavioural control over the behaviour (Madden et al. 1992). Ajzen (1991) describes two constructs relative to the theory of planned behaviour:

- Predicting behaviour: intentions,

- $\quad$ Perceived behavioural control.

\section{Predicting Behaviour: Intentions}

The original theory of reasoned action, a central factor in the theory of planned behaviour is the individual's intention to perform a given behaviour (Ajzen, 1991). Intentions are assumed to capture the motivational factors that influence behaviour, they are indications of how much of an effort people are planning to exert, to perform the behaviour. As a general rule, the stronger the intention to engage in a behaviour, the more likely should be its performance (Ajzen, 1991).

\section{Perceived Behavioural Control}

Ajzen (1991) states that the theory of planned behaviour differs from reasoned action in its addition of perceived behavioural control. Perceived behavioural control refers to people's perception of the ease or difficulty of performing the behaviour of interest and varies across situations and actions. Ajzen (1991) further states that another approach to perceived control can be found in theory of achievement motivation proposed by Atkinson (1964). An important factor in this theory is the expectancy of success, defined as the perceived probability of succeeding at a given task. According to the theory of planned behaviour, perceived behavioural control and behavioural intention can be used directly to predict behavioural achievement (Ajzen, 1991).

\section{Marketing Theory}

Efforts to develop a general, network-based marketing theory is called "many-to-many marketing", defined as the description, analysis and utilisation of the network properties of marketing (Gummesson, 2006; Gummesson, 2008). The marketing concept suggests companies that can address tourists' needs more efficiently and effectively than their competitors will achieve a competitive advantage in the tourism destination (Line \& Wang, 2017). Thus, companies that adopt a strategic posture that place tourists at the heart of strategic decision-making are market-oriented (Kohli \& Jaroskwi, 1990; Line \& Wang, 2017; Narver \& Slater, 1990). According to the marketing concept, the consumption and production of services 
are at least a partly simultaneous processes, and that the service provider partly enters the consumption sphere. Therefore, the production of services is an 'open system' for the tourist and the service provider (Grönroos, 1978; Gummesson, 1979; Lehtinen, 1983; Grönroos, 2006).

\section{Destination Image Theory}

Destination image theory in tourism research describes an induced-organic image dualism (Gunn, 1972; Hunter, 2013). Hunter (2013) suggests that induced and organic image perspectives might be mutually independent; the theory was refined into a set of three constructs, which include:

- Destination imagery, which refers to the tourist landscape and its material objects and experiences (Hunter, 2013; Wolcott, 1995),

- perceived destination image when exposed to destination imagery,

- $\quad$ projected destination image as the purposive generation and packaging of imagery in print and electronic forms for marketing or commentary (Gartner, 1994; Hunter, 2013: Pritchard \& Morgan, 2001).

\section{Perceptions of Local Residents Towards Tourism}

The perceived personal benefit of tourism to an individual, or dependence on it, and its relationship to attitudes has been previously explored (Ajzen, 1991; Andereck, Valentine, Knopf \& Vogt, 2005). In support of social exchange theory, the majority of studies have shown residents who are dependent on the industry, or perceive a greater level of economic gain or personal benefit, tend to have more positive perceptions of impact than others (Ajzen, 1991). Social exchange theory is a general sociological theory concerned with understanding the exchange of resources between individuals and groups in an interaction situation (Andereck et al. 2005; Ajzen, 1991).

\section{Destination Image}

It is common for destination image to be included in the tourist's decision-making (Cai, Feng \& Breiter, 2004; Clark \& McCleary, 1995; Leisen, 2001; Qu, Kim \& Im, 2011; Tasci \& Kozak, 2006). Destination image plays a special and unique role in tourists' decision-making and subsequent travel behaviour (Chuchu, Chiliya \& Chinomona, 2018). However, consumers in general receive various destination choices that provide similar features such as quality accommodations, beautiful scenic views, or friendly people. Taking from this perspective, the concept of destination branding is critical for a destination to be identified and differentiated from alternatives in the target market's minds. ( $\mathrm{Qu}$ et al. 2011). The image of a destination 
brand can be described as perceptions about the destination in the views of a (Cai, 2002). Therefore, destination branding can be is way to communicate a destination's unique identity by distinguishing it from its competitors (Qu et al. 2011). Similar to the general knowledge on brands, destination brands are responsible for identification and differentiation; this also applies to place marketing (Qu et al. 2011).

\section{Tourists' Willingness to Visit a Destination}

Increased competition for tourists among international destinations has underscored notions of quality and branding value as important factors that can make visiting a place more attractive (Murphy, Pritchard \& Smith, 2000). In destination marketing, value can be seen as a combination of a product's (destination's) perceived quality and associated price that a visitor will summarise as the value received (Murphy, et al. 2000). The marketing concept states that companies that adopt a strategic posture that places tourists at the heart of strategic decisionmaking are focused on the market (Kohli \& Jaworskwi, 1990; Narver \& Slater, 1990; Line \& Wang, 2017). Robben Island, of the coast of Cape Town is a major tourist attraction. Up to one thousand five hundred tourists may visit Robben Island during peak seasons. It is also one of the prime visitor attractions in and around Cape Town, including Table Mountain National Park, Cape Point and the Wine Routes. Together they form a package presenting both local and international visitors with an exciting and enriching experience that does not only talk to the visitor about the history of the region but also its geology and geomorphology, as well as human-to-human and human-to-environmental relations, over a long period of time (Robben Island Museum, 2017).

\section{Hypothesis Development}

According to the proposed conceptual framework, six were tested. These hypotheses are presented below:

\section{Predictor Variable: Destination Image}

According Qu et al. (2011), tourism destinations must be included in the consumers' evoked set, from which an ultimate decision is made (Cai, et al. 2004; Dana \& McClearly, 1995; Leisen, 2001; Tasci \& Kozak, 2006). However, consumers are generally offered various destination choices that provide similar quality accommodations, beautiful scenic views, or friendly people. Therefore, it is not enough for a destination to be included in the evoked set, instead the destination needs to be unique and differential to be selected as a final decision. From this perspective, the concept of destination branding is critical for a destination to be identified and differentiated from alternatives in the minds of the target market (Qu et al. 2011). 
The image of a destination brand can be described as perceptions about the place as reflected by the associations held in tourist memory (Cai, 2002).

\section{Predictor Variable: Perceptions of Local Residents towards Tourists}

The perceived personal benefit of tourism to an individual, or dependence on it, and its relationship to attitudes has been previously explored (Ajzen, 1991; Andereck et al. 2005). In support of social exchange theory, most studies have shown that residents who are dependent on the industry or perceive a greater level of economic gain or personal benefit, tend to have more positive perceptions of an impact than others (Ajzen, 1991). Social exchange theory is a general sociological theory concerned with understanding the exchange of resources between individuals and groups in an interaction situation (Ajzen, 1991; Andereck et al. 2005). Sociocultural impacts (Brunt \& Courtney, 1999), socio-demographics (Williams \& Lawson, 2001), and culture (Besculides, Lee \& McCormick, 2002), are some of the factors that have been examined. Since positive and negative impacts are likely to result, large-scale ventures should be undertaken through local enterprises and consistent with the values of host communities (Brunt \& Courtney, 1999; Williams \& Lawson, 2001; Besculides et al. 2002; Duffield \& Long, 1981). Perceptions are associated with the outward behaviour of people. If an individual has a positive perception of tourism, they will support tourism activities. Likewise, when local residents perceive tourism in positively, they are likely to display a positive attitude towards tourists, which will lead to tourists having a favourable image of the destination, and tourists will be willing to revisit the destination. Stemming from the literature above, the following hypothesis is presented.

$\mathrm{H}_{1}$ : Perceptions of local residents towards tourism has a positive relationship with tourists' willingness to visit a destination.

\section{Perceptions of Local Residents towards Tourism and Local Residents' Attitudes towards}

\section{Tourism}

Engagement from the community is critical for tourism initiatives (Mokoena, Dhurup, Surujlal, 2016; Thomas, 2013). For successful sustainable development in tourism to occur, the attitudes of residents are a significant predictor. For a tourism destination to be successfully managed, the attitudes of local residents are of utmost importance (Wang \& Pfister, 2008, Rastegar, 2010, Sharma \& Dyer, 2009; Mokoena et al. 2016). Since perceptions determine an individual's behaviour towards an object or situation, if local residents have positive perceptions towards tourism, these perceptions will positively influence their attitudes and actions towards tourism. On the other hand, if local residents' have negative perceptions 
towards tourism, they are most likely to reject tourism developmental plans and activities. Therefore, local residents may also act negatively towards tourists. The consequences of negative behaviour displayed may have detrimental effects on the local economy, as tourists may not revisit the destination or publicly share their negative experiences. Based on the abovementioned literature, the following hypothesis is proposed.

$\mathrm{H}_{2}$ : Perceptions of local residents towards tourism have a positive relationship with local residents' attitudes towards tourism.

\section{Perceptions of Local Residents towards Tourism and Destination Image}

Destination image refers to impressions of a place or perceptions of an area and the destination's mental image (Echtner \& Ritchie, 2003; Pan \& Li, 2011; Mokoena et al. 2016). Local residents' perceptions towards tourists and tourism can be positive, if they acknowledge that the recreational facilities in local areas are being upgraded due to tourism, and they are also able to enjoy the use of these facilities (Brida et al. 2011; Gursoy, Jurowski \& Uysal, 2002). Many prior research articles focus on tourists' perceptions of destination image, but there is limited research-based on local residents' perceptions regarding destination image. If local residents believe that tourism is having a positive effect on their lives and the local city is being upgraded due to increased tourism, they will feel a sense of pride about the city in which they reside. If locals support tourism, tourism planning and developmental activities will be more efficient and effective as compared to locals who do not support tourism. Based on the evidence provided, the following hypothesis in proposed.

$H_{3}$ : Perceptions of local residents towards tourism are related to destination image.

\section{Destination Image and the Attitudes of Local Residents towards Tourism}

Locals tend to have positive attitudes because they see tourism as an economic development tool. However, local residents' perceptions of tourism impacts and their level of tourism support tend to change as a destination moves from one stage of its life cycle to the next Gursoy, Chi \& Dyer, 2010). Destination image influences traveller intention according to (Chen \& Tsai, 2007; Chuchu, 2020). A step that can be taken may include monitoring changes in locals' perceptions and attitudes and identifying new development initiatives that may be supported by locals (Gursoy et al. 2010). Since perceptions determine attitudes, it is clear that positive perceptions lead to positive attitudes, ultimately determining if local residents are willing to support tourism. Local service providers must highlight that the improvement or creation of local facilities will improve the lifestyle of residents. Marketers must also find strategies to create employment for residents to encourage the development of tourism 
facilities. Residents should encourage rather than display hostility towards tourism development. The following hypothesis is proposed.

$\mathrm{H}_{4}$ : Destination image is related to attitudes of local residents' towards tourism.

\section{Destination Image and Tourists' Willingness to Visit a Destination}

Destination image is a multi-dimensional construct influenced by cognitive, unique and effective images that together influence tourist behaviour. Image, therefore, plays a mediating role between the cognitive, unique and effective brand associations and behavioural intentions (Maumbe \& Van Wyk, 2016; Qu, et al. 2011). Maumbe \& Van Wyk (2016) stated that brand image is regarded as tourists' and potential tourists' hold about the destination. Many factors contribute to the image of a destination: recreational activities, weather conditions, safety and security, and various other factors. The marketer must find ways to strategically highlight the unique features and capabilities of the destination to build a favourable destination image in the minds of tourists. When a destination has adopted a negative image, it is difficult for marketers to reposition their destination image. This is because tourists have numerous other destinations they may have in their evoked set. Therefore, marketers must uphold a favourable and enticing reputation for the destination. The following hypothesis is proposed.

$\mathrm{H}_{5}$ : Destination image is related to tourists' willingness to visit a destination.

\section{Attitudes of Local Residents towards Tourism and Tourists' Willingness to Visit a}

\section{Destination}

An attitude is an evaluation of an object of thought (Bohner \& Dickel, 2011). Attitude objects comprise of anything a person may hold in their mind, ranging from the mundane to the abstract, including things, people, groups, and ideas (Bohner \& Dickel, 2011). A tourist's attitude is the general evaluation of a tourist's specific behaviour (Çelik \& Yilmaz, 2011; Gumpo, Chuchu, Maziriri \& Madinga, 2020). To measure inevitable tourism impacts on local population, and the perceptions developed and reactions displayed by residents should be investigated, thus an analysis of attitudes from the local residents should be involved (Brida et al. 2011). Comprehension of consumer attitudes allows for adopting an adequate responsive mechanism to the negative influences that arise from the tourism exchange (Brida et al. 2011; Williams \& Lawson, 2001; Sharma \& Dyer, 2009). Attitudes are assumed to be a factor in predicting tourist's behaviour, but without intention to behave, this assumption could be challenged (Park \& Boo, 2009). The following hypothesis is proposed.

$\mathrm{H}_{6}$ : Attitudes of local residents' towards tourism are related to tourists' willingness to visit a destination. 


\section{Conceptual Model}

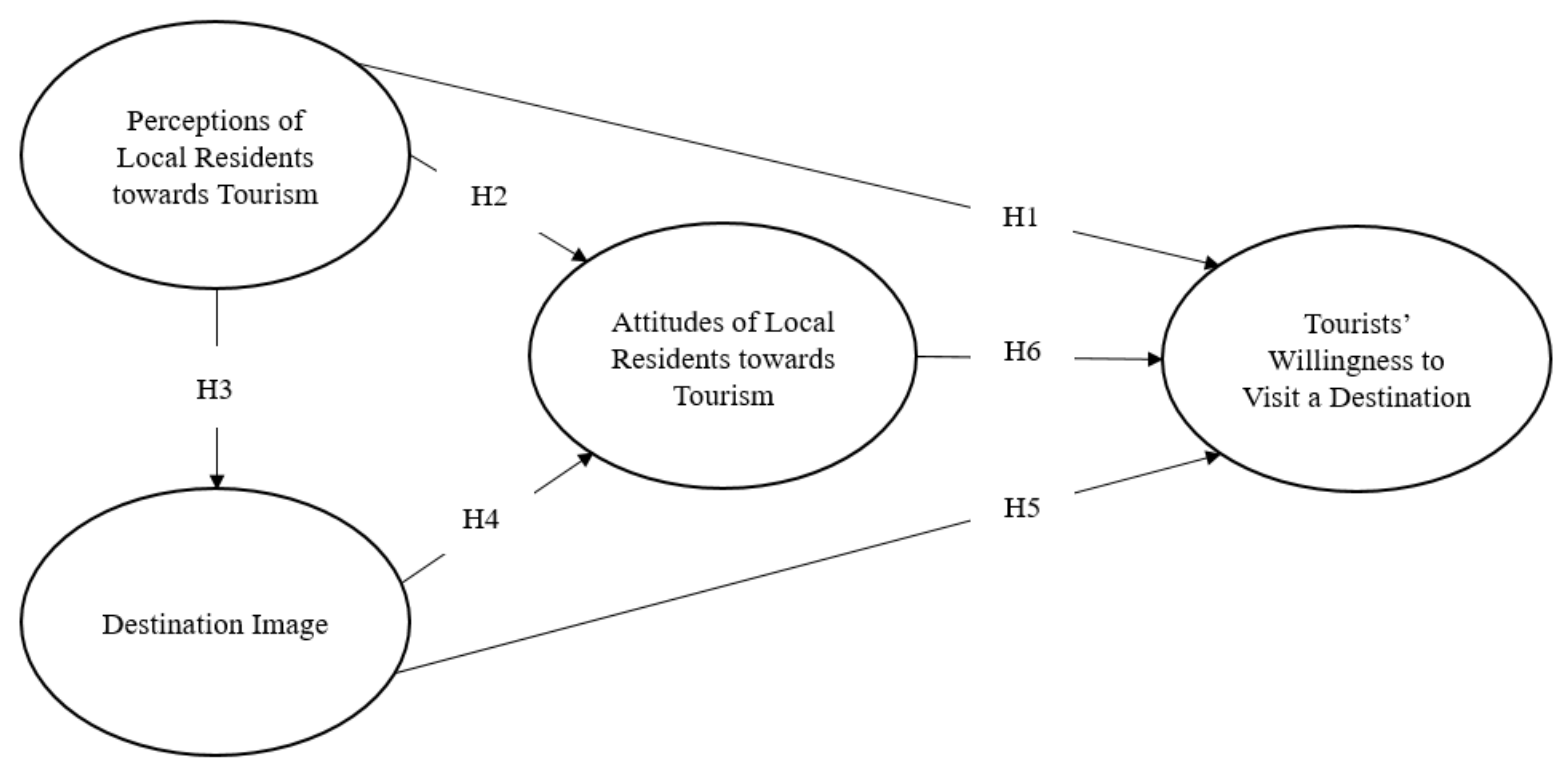

Figure 1: Conceptual Model

\section{RESEARCH METHOD}

\section{Research Design and Sampling}

The research was quantitative in nature adopting the survey method. Due to the absence of sampling frame, convenience sampling, a form of non-probability sampling was used to select participants. The sample comprised of 270 willing participants. This sample size was calculated based on the number of questions following the approach recommended by (Hair, Black, Babin, \& Anderson, 2010). The operational definition of variables are discussed. First, destination image refers to attitudinal theory encompassing the views, ideas, and perceptions that tourists hold toward a destination (Hosany, Ekinci \& Uysal, 2006). Second, perceptions of local residence towards tourism are the beliefs associated with tourism (Sinclair-Maragh, Gursoy \& Vieregge, 2015) that local residence would hold. Third, attitudes of local residence towards tourism refers to the behaviours that result when tourist are influenced (Patroni, Day, Lee, Chan, Kim, Kerr, Newson \& Simpson, 2018). Within the context of the study, this referred to local residents. The definition for the last variable, tourists' wiliness to visit a destination refers to one's preparedness to make a repeat visit to the same destination (Stylos, Vassiliadis, Bellou \& Andronikidis, 2016).

The hypotheses were based on the abovementioned four variables, the first hypotheses $\left(\mathrm{H}_{1}\right)$ was to test the impact of perceptions of local residents towards tourism on tourists' willingness to visit a destination. The second hypotheses $\left(\mathrm{H}_{2}\right)$ was to test the relationship 
between perceptions of local residents towards tourism and attitudes of local residents towards tourism while the third hypothesis $\left(\mathrm{H}_{3}\right)$ was to measure the impact of perceptions of local residents towards tourism on destination image. The fourth hypothesis $\left(\mathrm{H}_{4}\right)$, was to assess the effect of destination image on attitudes of local residents towards tourism while the fifth hypothesis $\left(\mathrm{H}_{5}\right)$ tested the relationship between destination image and tourists' willingness to visit a destination. The last hypothesis, hypothesis, $\left(\mathrm{H}_{6}\right)$, was to test the relationship between attitudes of local residents towards tourism and tourists' willingness to visit a destination.

\section{Measurement Instrument}

According to Hair et al. (2010) the general rule is to have a minimum of 5 observations per variable (5:1), and acceptable sample size would have 10 observations per variable (10:1). The responses were collected based on a five-point Likert scale based rated from "strongly disagree" to "strongly agree" in relation to the statements presented to the participants. The questionnaire measured four variables; perception of local residents towards tourism. The present research has 20 Likert-scale questions (items) requiring 200 observations. The sample of 270 exceeded the recommended one of 200 . The composition of the items was perceptions of local residents towards tourism (P) 10 items, destination image (DI) 10 items, attitudes of local residents towards tourists (AT) 10 items and tourists' willingness to visit a destination (TWV) 10 items.

\section{Data analysis}

The collected data was processed in SPSS 24 and AMOS 24 for descriptive results and inferential statistics respectively. In terms of descriptive results; gender, age, educational and residential status frequencies were generated. As for inferential statistics, structural equation modeling was conducted following the two-step approach proposed by Hair et al. (2010) which begins with confirmatory factor analysis followed by hypotheses testing. Confirmatory factor analysis was conducted to establish scale validity and model fit while hypotheses testing was conducted to investigate causality of proposed hypotheses and relationship strength.

\section{Ethical considerations}

Prior to data collection, the institution responsible for granting permission to conduct the study granted the researchers ethical clearance. Participants were fully briefed about the study prior to participation. Participation was voluntary and remained anonymous granting participants an opportunity to withdraw from the study at any point. Data collected was only used for purposes of the research as explained to the participants. The following section presents the results of the study followed by a discussion. 


\section{RESULTS AND DISCUSSION}

Tabel 1 presents the sample profile of the study. As indicated in the table 1 male and female participants were evenly distributed and as for age, 18- to 25-year-olds accounted for most of the participants. The majority of the participants were undergraduate students as indicated by $44 \%$. The majority of the respondents indicated that they resided in the suburbs, followed by those in the township and lastly by urban city residents. Cape Town visitors were evenly spread while three quarters of these visitors mentioned that they visited Robben Island.

Table 1: Sample Demographic Profile

\begin{tabular}{lcc}
\hline Gender & Frequency & Percentage \\
\hline Male & 127 & $47.0 \%$ \\
Female & 142 & $52.6 \%$ \\
Not Specified & 1 & $0.4 \%$ \\
Total & $\mathbf{2 7 0}$ & $\mathbf{1 0 0} \%$ \\
\hline Age & Frequency & Percentage \\
\hline $18-25$ & 182 & $67.4 \%$ \\
$26-35$ & 61 & $22.6 \%$ \\
$36-45$ & 19 & $7.0 \%$ \\
46-55 & 6 & $2.2 \%$ \\
55+ & 2 & $0.7 \%$ \\
Total & $\mathbf{2 7 0}$ & $\mathbf{1 0 0} \%$ \\
\hline Level of Study & Frequency & Percentage \\
\hline Matric & 42 & $15.6 \%$ \\
Certificate & 19 & $7.0 \%$ \\
Diploma & 20 & $7.4 \%$ \\
Undergraduate & 119 & $44.1 \%$ \\
Post Graduate & 67 & $24.8 \%$ \\
Other & 3 & $1.1 \%$ \\
Total & $\mathbf{2 7 0}$ & $\mathbf{1 0 0} \%$ \\
\hline Residential Environment & Frequency & Percentage \\
\hline Township & 63 & $23.3 \%$ \\
Urban City & 56 & $20.7 \%$ \\
Suburb & 142 & $52.6 \%$ \\
Other & 9 & $3.3 \%$ \\
Total & $\mathbf{2 7 0}$ & $\mathbf{1 0 0 \%}$ \\
\hline Have you visited/ lived in Cape Town? & Percentage \\
\hline Yes & 156 & $57.8 \%$ \\
No & $\mathbf{2 7 0}$ & $42.2 \%$ \\
Total & $\mathbf{1 0 0} \%$ \\
\hline Have you visited Robben Island? & $\mathbf{1 0} \%$ \\
\hline Yes & $\mathbf{2 7 0}$ & Percentage \\
No & & $29.3 \%$ \\
\hline Total & $70.7 \%$ \\
\hline & $\mathbf{1 0 0 \%}$ \\
\hline & & \\
\hline & & \\
\hline
\end{tabular}




\begin{tabular}{|c|c|c|c|c|c|c|c|c|c|}
\hline \multicolumn{6}{|c|}{$\begin{array}{l}\text { ISSN 2623-0690 (Cetak) } \\
\text { 2655-3813 (Online) }\end{array}$} & \multicolumn{4}{|c|}{$\begin{array}{r}\text { Business Management Analysis Journal (BMA } \\
\text { Vol. } 4 \text { No. } 2 \text { Oktober } 202\end{array}$} \\
\hline \multirow{2}{*}{\multicolumn{2}{|c|}{$\begin{array}{l}\text { Research } \\
\text { Construct }\end{array}$}} & \multicolumn{4}{|c|}{ Descriptive Statistics } & \multicolumn{2}{|c|}{$\begin{array}{c}\text { Cronbach's } \\
\text { Test }\end{array}$} & \multirow{2}{*}{$\begin{array}{c}\text { CR } \\
\text { Value }\end{array}$} & \multirow{2}{*}{$\begin{array}{l}\text { Factor } \\
\text { Loading }\end{array}$} \\
\hline & & Mean & Value & $\begin{array}{l}\text { Stai } \\
\text { Dev }\end{array}$ & $\begin{array}{l}\text { ard } \\
\text { tion }\end{array}$ & $\begin{array}{l}\text { Item- } \\
\text { total }\end{array}$ & $\begin{array}{l}\text { alpha } \\
\text { value }\end{array}$ & & \\
\hline \multirow{4}{*}{$\mathbf{P}$} & $\mathrm{P} 1$ & 1,852 & \multirow{4}{*}{2,355} & 1,223 & & 0,422 & \multirow{4}{*}{0,612} & \multirow{4}{*}{0,686} & 0,775 \\
\hline & P3 & 3,059 & & 1,165 & 1105 & 0,346 & & & 0,091 \\
\hline & $\mathrm{P} 4$ & 2,041 & & 1,193 & 1,195 & 0,464 & & & 0,832 \\
\hline & P5 & 2,467 & & 1,200 & & 0,432 & & & 0,575 \\
\hline \multirow{5}{*}{ DI } & DI1 & 2,315 & \multirow{5}{*}{2,261} & 1,241 & & 0,619 & \multirow{5}{*}{0,807} & \multirow{5}{*}{0,834} & 0,678 \\
\hline & DI2 & 2,604 & & 0,864 & & 0,454 & & & 0,350 \\
\hline & DI3 & 2,278 & & 0,972 & 1,090 & 0,592 & & & 0,678 \\
\hline & DI4 & 2,081 & & 1,211 & & 0,661 & & & 0,686 \\
\hline & DI5 & 2,026 & & 1,161 & & 0,658 & & & 0,749 \\
\hline \multirow{5}{*}{ AT } & AT1 & 2,841 & \multirow{5}{*}{2,272} & 1,091 & & 0,281 & \multirow{5}{*}{0,698} & \multirow{5}{*}{0,723} & 0,192 \\
\hline & AT2 & 2,348 & & 1,096 & & 0,315 & & & 0,250 \\
\hline & AT3 & 2,011 & & 1,086 & 1,081 & 0,576 & & & 0,761 \\
\hline & AT4 & 2,015 & & 1,077 & & 0,636 & & & 0,856 \\
\hline & AT5 & 2,144 & & 1,055 & & 0,493 & & & 0,750 \\
\hline \multirow{5}{*}{ TWV } & TWV1 & 1,952 & \multirow{5}{*}{2,038} & 1,035 & & 0,737 & \multirow{5}{*}{0,879} & \multirow{5}{*}{0,898} & 0,815 \\
\hline & TWV2 & 2,067 & & 1,109 & & 0,709 & & & 0,738 \\
\hline & TWV3 & 2,137 & & 0,964 & 1,033 & 0,916 & & & 0,757 \\
\hline & TWV4 & 2,052 & & 1,023 & & 0,705 & & & 0,854 \\
\hline & TWV5 & 1,981 & & 1,033 & & 0,697 & & & 0,710 \\
\hline
\end{tabular}

Key: $P=$ Perceptions of local residents towards tourism, $D I=$ Destination Image, $A T=$ Attitudes of local residents towards tourists, $T W V=$ Tourists' willingness to visit a destination, $C R=$ Composite Reliability.

Table 3: Model Fit Indices

\begin{tabular}{lccccccc}
\hline $\begin{array}{c}\text { Model fit } \\
\text { criteria }\end{array}$ & $\left(\chi_{2} / \mathbf{D F}\right)$ & CFI & GFI & NFI & IFI & TLI & RMSEA \\
\hline $\begin{array}{l}\text { Indicator } \\
\text { value }\end{array}$ & 1,499 & 0,975 & 0,931 & 0,931 & 0,976 & 0,965 & 0,043 \\
\hline$(\chi 2 / D F):$
\end{tabular}

( 2 /DF): Chi-square, CFI: Confirmatory factor analysis, GFI: Goodness of fit index, NFI: Normed fit index, IFI: Incremental fit index, IFI: Incremental fit index, TLI: Tucker Lewis Index, RMSEA: Root measure of standard error approximation.

Reliability and validity measure are presented in table 2 . It can be observed in the table 2 that all the mean values ranged from 2,038 to 2,355 while the standard deviation values ranged from 1,033 to 1,195 . This proved that there was normal distribution of data as the means where within close proximity and the standard deviation value were found to be between -2 
and +2 . All Cronbach alpha and composite reliability $(\mathrm{CR})$ values reached the required threshold of 0.6 .

Model fit indices are presented in table 3. The table provides the model fit indices for the study where all the indices met the respective required thresholds. Figure 2 the structural model shows interrelatedness of the constructs.

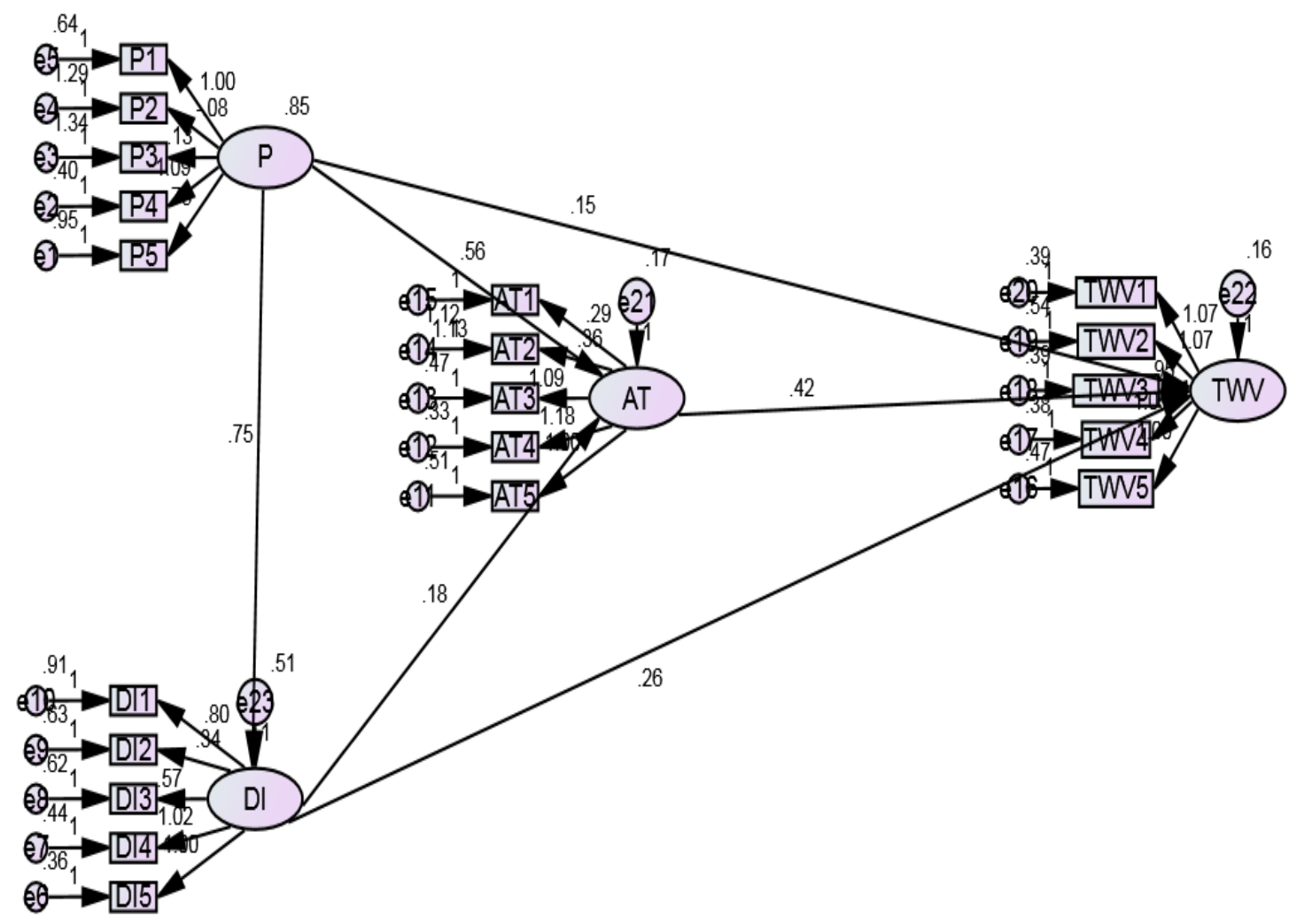

Key: $P=$ Perceptions of local residents towards tourism, DI= Destination Image, AT= Attitudes of local residents towards tourists, $T W V=$ Tourists' willingness to visit a destination, $e=$ measurement error

Figure 2: Structural Model

\section{Summary of Hypothesis Results}

Table 4 shows that all the hypotheses coefficients were at a significant level of $\mathrm{P}<0.01$. Hypothesis one, two and three $\left(\mathrm{H}_{1}, \mathrm{H}_{2}, \mathrm{H}_{3}\right)$, showed that perceptions of local residents' towards tourists had a positive and direct relationship with tourists' willingness to visit a destination, attitudes of local residents' towards tourists and destination image. Since all three hypotheses were supported, this indicates that local residents' perceptions towards tourists have a meaningful and significant impact on local residents' attitudes towards tourists and destination 
image, which also affects tourists' willingness to visit a destination. P2 was removed from the results as none of the results from $\mathrm{P} 2$ reached the model fit results threshold.

Table 4: Results of Structural Equation Model Analysis

\begin{tabular}{|c|c|c|c|c|}
\hline Proposed Relationship Hypothesis & Hypothesis & Estimate & P-value & $\begin{array}{c}\text { Supported/ } \\
\text { Rejected }\end{array}$ \\
\hline $\begin{array}{l}\text { Perceptions of local residents } \\
\text { towards tourism - Tourists' } \\
\text { willingness to visit a destination. }\end{array}$ & $\mathrm{H}_{1}$ & 0.15 & $* * *$ & $\begin{array}{l}\text { Supported and } \\
\text { significant }\end{array}$ \\
\hline $\begin{array}{l}\text { Perceptions of local residents } \\
\text { towards tourism - Local residents' } \\
\text { attitudes towards tourists. }\end{array}$ & $\mathrm{H}_{2}$ & 0.56 & $* * *$ & $\begin{array}{l}\text { Supported and } \\
\text { significant }\end{array}$ \\
\hline $\begin{array}{l}\text { Perceptions of local residents } \\
\text { towards tourism - Destination } \\
\text { image. }\end{array}$ & $\mathrm{H}_{3}$ & 0.75 & 0.005 & $\begin{array}{l}\text { Supported and } \\
\text { significant }\end{array}$ \\
\hline $\begin{array}{l}\text { Destination image - Attitudes of } \\
\text { local residents' towards tourism. }\end{array}$ & $\mathrm{H}_{4}$ & 0.18 & $* * *$ & $\begin{array}{l}\text { Supported and } \\
\text { significant }\end{array}$ \\
\hline $\begin{array}{l}\text { Destination image - Tourists' } \\
\text { willingness to visit a destination. }\end{array}$ & $\mathrm{H}_{5}$ & 0.26 & 0.124 & $\begin{array}{l}\text { Supported but not } \\
\text { significant }\end{array}$ \\
\hline $\begin{array}{l}\text { Attitudes of local residents' } \\
\text { towards tourism - Tourists' } \\
\text { willingness to visit a destination. }\end{array}$ & $\mathrm{H}_{6}$ & 0.42 & $* * *$ & $\begin{array}{l}\text { Supported and } \\
\text { significant }\end{array}$ \\
\hline
\end{tabular}

Hypothesis four $\left(\mathrm{H}_{4}\right)$ posited that destination image is positively and directly related to attitudes of local residents towards tourism. Since this hypothesis is supported, it indicates that the image of the host destination has an important and significant impact on the attitudes of local residents' living in that destination, towards tourists. Hypothesis five $\left(\mathrm{H}_{5}\right)$ posits that destination image is positively and directly related to tourists' willingness to visit a destination. $\mathrm{H}_{5}$ is supported but not significant, indicating that the image of the destination is related to tourists' willingness to visit that destination. However, this does not play a major role in the tourists' decision-making in terms of visiting a destination. Hypothesis six $\left(\mathrm{H}_{6}\right)$ reveals that local residents' attitudes towards tourism are positively and directly related to tourists' willingness to visit a destination. $\mathrm{H}_{6}$ is both supported and significant, indicating that the attitudes of local residents towards tourists have a significant impact on tourists' willingness to visit a destination.

\section{Implications}

The current research study has both academic and practical implications. With regard to academic implications, this research study contributes to existing literature on destination 
image, and the relationship between the attitudes and perceptions of local residents towards tourists and tourists' willingness to visit a destination. Tourism marketers must understand the perceptions in the minds of local residents towards tourists that lead to local residents' attitudes, weather favourable or unfavourable, which may impact tourists' willingness to visit a destination. The perceptions of local residents towards tourists positively affect tourists' willingness to visit a destination. This implied that if local residents perceived tourists favourably, local people are more likely to display positive behaviour towards tourists and encourage tourism. Perceptions of local residents towards tourists has a positive relationship with the attitudes of local residents towards tourists. This relationship implied that the perceptions local residents' have about tourists, ultimately influence their behaviour towards tourists. Since the relationship was positive, there is a high possibility that local residents' behaviour towards tourists will be influenced by the positive perceptions that residents' have in their minds; these behaviours may include creating a welcoming environment for tourists.

The relationship between the perceptions of local residents towards tourists and destination image is also a positive relationship. This positive relationship may be due to local residents believing that increased tourism enhances the lives of local people thereby positively affecting upliftment. If residents feel that increased tourism creates job opportunities, then local residents, especially those living in poorer communities, may welcome more tourists to visit the destination. Destination image has a positive relationship with the attitudes of local residents towards tourists. A factor that may support this relationship is that, if local residents are able to benefit and enjoy recreational facilities within the area that are primarily created for tourists, local residents will respond to tourists favourably. Destination image has a positive relationship with tourists' willingness to visit a destination. This may be explained in terms of the perception that tourists' have of a destination. These perceptions may emanate from numerous factors such as previous experiences at the destination or, marketing efforts put forward by marketers.

Marketers must create a positive destination image that is able to resonate with potential tourists. Service providers at the destination must provide the best possible experience for tourists. This may lead to the tourists adding the location to an evoked set of destination choices, or creating favourable experience reviews on social media or reference groups. Attitudes of local residents towards tourists has a positive relationship with tourists' willingness to visit a destination. This implies that if local residents have a positive attitude towards tourists, then tourists will feel welcomed, but if local residents display a negative 
attitude towards tourists, this could create a hostile environment and lead to fewer tourists visiting the area in the future. It is essential for tourists to feel a sense of belonging when visiting a foreign area, as they are much more vulnerable, due to being in a foreign area and out of their comfort zone. Implications for marketing managers may include making local residents aware of any proposed developments in local areas. If local residents are unaware of developmental changes to the area in which they reside, this may lead to resentment and a negative attitude emanating from residents. Mid-term to long-term infrastructure developmental plans may affect the lives of residents. This point is especially important with regard to poorer areas, where a new recreational facility within close proximity, may require that informal settlements are destroyed.

\section{Theoretical Contributions}

The research study contributes to the literature on the perceptions of local residents towards tourists. Based on the findings from the study, perceptions of local residents towards tourists have a positive impact on local residents' attitudes towards tourists and destination image. Perdue et al 1990, state that the perceived personal benefit of tourism to an individual, or dependence on it, and its relationship to attitudes has been previously explored. In support of social exchange theory, the majority of studies have shown residents who are dependent on the industry, or perceive a greater level of economic gain or personal benefit, tend to have more positive perceptions of impact than others (Brunt \& Courtney, 1999). The theory of planned behaviour, incorporates perceived behavioural control as an ascendant to behavioural intentions (Madden, et al. 1992). Another contribution made by study was the positive relation between destination image and tourists' willingness to visit a destination. Qu et al. 2011 state it is widely acknowledged that tourism destinations must be included in the consumers' evoked set, from which an ultimate decision is made (Cai et al. 2004; Dana \& McClearly, 1995; Leisen, 2001; Tasci \& Kozak, 2006).

Chang \& Wildt (1994) advise that value can be seen as combination of a product's (destination's) perceived quality and associated price which a visitor will summarise as the value received (Murphy et al. 2000). The study also made a contribution the attitudes of local residents towards tourists that found a positive relationship with tourists' willingness to visit a destination. Understanding people's attitudes means understanding if residents are supportive or exert opposition towards tourism development projects (Brida et al. 2011; Sharma \& Dyer, 2009; Williams \& Lawson, 2001). 


\section{Marketing Contributions}

The marketing contributions of this research study include:

- Enabling marketers to make better tourism planning decisions by considering the local community's needs; thereby enabling the tourism marketing process to be more efficient.

- Marketers are able to understand that creating awareness and knowledge in the local community regarding the various benefits (improved infrastructure, injection into the local economy, improved lifestyle) of tourism, will make their tourism marketing efforts more effective.

- Marketers must ensure that local service providers offer consistent and exceptional customer service to tourists and the local community. This is done to build a favourable destination image and secure repeat visitors.

- Marketers should find strategies that reward local residents' who support tourism initiatives. An incentive-based strategy will be a motivator within the community, which reinforces tourism efforts from local residents.

The managerial implications arising from the results of this study, suggest that marketing managers of tourism in Cape Town should focus on increasing brand awareness of the City of Cape Town, as destination image was seen to have the strongest influence on the perceptions of local residents towards tourists. If local residents are proud of their city of residence, they will be more accommodating to tourists. This may be achieved by creating more job opportunities for local residents within tourist attractions. By creating more job opportunities for local residents, residents may become more favourable to tourists and have a greater sense of pride with their perceptions towards tourists. It may also positively influence local residents' attitudes towards tourists. This will attract more tourists to Cape Town and Robben Island as local residents become more welcoming and accepting of tourists.

\section{E. CONCLUSION}

The research was focused on destination marketing from the perspective of local tourists. A unique conceptual model was to developed to aid in understanding and measuring perceptions of these local tourists. Perceptions of local residents towards tourism, attitudes of local residents toward tourism, tourists' willingness to visit a destination and destination image were all measured in the research. This study aimed to investigate perceptions of local tourists, attitudes, and willingness to visit local destinations. Further research suggestions of the topic cover to main categories. First, there are practical suggestions, for instance, making use of more 
than a single geographic region for the study, Cape Town. This could have produced both researcher and participant bias. This is because both the researcher and participants would likely hold pre-conceived perceptions of the destination. This could have influenced the questioning on the part of the researcher, the interpretation of the questions by the participants, and the interpretation of results by the researcher. Second, this research made use of readily available residence of South Africa, accessed in the nation's busiest city, Johannesburg with some knowledge of subject area (Cape Town). It would therefore be recommended for further research to conduct fieldwork on-site. This would mean that local tourists would be intercepted in real time as they actually experience the Cape Town tourism scene. The present research made use of people who had to respond to the study's questions relying on their experiences in Cape Town and the time lapse could have lowered the quality of their responses.

After factoring-in the practical suggestions mentioned above, conceptual suggestions for further research can be made. This would mean that, potential hypotheses not tested in the present research could then be tested or eliminating hypotheses from the present research to see how that would affect the entire model or specific relationships in the model. It would be suggested that the last hypothesis, H4 (attitudes of local residents' is related to tourists' willingness to visit a destination) be eliminated from the model. This could affect the impact that the predictors have on the mediator, resulting in potentially significant changes to the conceptual model. This would then generate different findings for the entire model. It would be interesting to find-out the impact of "perceptions of local residents towards tourism" and "destination image on attitudes of local residents towards tourism" if the relationship between the "attitudes of local residence towards tourism" and "tourists' willingness to visit a destination" is eliminated.

\section{Limitations and Future Research Suggestions}

This study like any other had its fair share of limitations. First, the study was purely quantitative, this limited the extent to which participants could express themselves. This is because a limited Likert-scale questionnaire was used to collect responses from participants. This could have resulted in local tourists attitudes being partially or not fully measured regarding their attitudes towards tourism. It would be beneficial if future research incorporates a qualitative aspect through the form of in-depth interviews. Since local tourists would not be restricted by a structured scale, the will be able to provide responses with rich depth and provide deeper insights on the topic. The second limitation was that the study focused on participants 
from a single region. This could have introduced respondent bias into the study as these participants were exposed to the same environment and could have been influenced by similar geographic social, political and economic factors. Further research should utilise a more diverse sample of local tourists as this will provide more objective feedback brought through varying perspectives. As for conceptual recommendations, the current model could be modified through the analysis of potential hypotheses that were not test in this study. For example, it would be interesting to understand the moderating effect of attitudes of local residents towards tourists between perceptions of local residents towards tourism and destination Image. This could contribute in expanding the discussion of the topic concerning perceptions of local residence towards tourism.

\section{REFERENCES}

Ajzen, I., \& Fishbein, M. (1980). Understanding attitudes and predicting social behavior. Englewood Cliffs, NJ: Prentice-Hall.

Ajzen, I., (1991). The theory of planned behaviour. Organisational behaviour and human decision processes, 50(2), pp.179-211.

Andereck, K. L., Valentine, K. M., Knopf, R. C., \& Vogt, C. A. (2005). Residents' perceptions of community tourism impacts. Annals of tourism research, 32(4), 10561076.

Atkinson, J. W. (1964). An introduction to motivation. Princeton, NJ: Van Nostrand.

Babin, B. J., \& Zikmund, W. G. (2015). Exploring marketing research. Cengage Learning.

Besculides, A., Lee, M. E., \& McCormick, P. J. (2002). Residents' perceptions of the cultural benefits of tourism. Annals of tourism research, 29(2), 303-319.

Bohner, G., \& Dickel, N. (2011). Attitudes and Attitude Change. Annual Review of Pyschology. 62 (1), 391-417.

Brida, J., G., Osti, L., \& Faccioli, M. (2011). Residents' perception and attitudes towards tourism impacts: A case study of the small rural community of Folgaria (Trentino Italy). Benchmarking: An International Journal, 18 (3), 359-385.

Brunt, P., \& Courtney, P. (1999). Host perceptions of sociocultural impacts. Annals of tourism Research, 26(3), 493-515.

Bryden, J. (1973) Tourism and Development: A Case Study of the Commonwealth Caribbean, London: Cambridge University Press.

Cai, L. A. (2002). Cooperative branding for rural destinations. Annals of tourism research, 29(3), 720-742.

Cai, L. A., Feng, R., \& Breiter, D. (2004). Tourist purchase decision involvement and information preferences. Journal of vacation Marketing, 10(2), 138-148. 
Çelik, H.E. \& Yilmaz, V. (2011). Extending the technology acceptance model for adoption of e-shopping by consumers in Turkey. Journal of Electronic Commerce Research,

Chang, T. Z., \& Wildt, A. R. (1994). Price, product information, and purchase intention: An empirical study. Journal of the Academy of Marketing science, 22(1), 16-27.

Chen, C. F., \& Tsai, D. (2007). How destination image and evaluative factors affect behavioral intentions? Tourism management, 28(4), 1115-1122.

Chuchu, T. (2020). The Impact of Airport Experience on International Tourists' Revisit Intention: A South African Case. Geojournal of Tourism and Geosites, 29(2), 414-427.

Chuchu, T., Chiliya, N., \& Chinomona, R. (2018). The impact of servicescape and traveller perceived value on affective destination image: an airport retail services case. The Retail and Marketing Review, 14(1), 45-57

Clark, J. D., \& McCleary, K. W. (1995). Influencing associations' site-selection process. The Cornell Hotel and Restaurant Administration Quarterly, 36(2), 5-68.

Dana, C. J., \& McClearly, K. W. (1995). Influencing associations' site-selection process. Cornell Hotel and Restaurant Administration Quarterly, 36(2), 61-68.

Duffield, B. S., \& Long, J. (1981). Tourism in the highlands and islands of Scotland rewards and conflicts. Annals of tourism research, 8(3), 403-431.

de Kadt, E. (1979). Social planning for tourism in the developing countries. Annals of Tourism Research, 6(1), 36-48.

Echtner, C. M., \& Ritchie, J. B. (2003). The meaning and measurement of destination image. Journal of tourism studies, 14(1), 37-48.

Fallon, L. D., \& Kriwoken, L. K. (2003). Community involvement in tourism infrastructurethe case of the Strahan Visitor Centre, Tasmania. Tourism Management, 24(3), 289308.

Fishbein, M., Jaccard, J., Davidson, A. R., Ajzen, I., \& Loken, B. (1980). Predicting and understanding family planning behaviors. In Understanding attitudes and predicting social behavior. Prentice Hall.

García.F.A., Vázquez A.B., Macías.R.C. (2015). Resident's attitudes towards the impacts of tourism. Tourism Management Perspectives, 13 (1), p33-40.

Grönroos, C. (2006). Adopting a service logic for marketing. Marketing theory, 6(3), 317333.

Gummesson, E. (1979). The marketing of professional services - An organizational dilemma. European Journal of Marketing, 13(5), 308-318.

Gummesson, E. (2006). Qualitative research in management: addressing complexity, context and persona. Management Decision, 44(2), 167-179.

Gummesson, E. (2008). Extending the service-dominant logic: from customer centricity to balanced centricity. Academy of Marketing Science, 10 (36), 15-17. 
Gumpo, C.I.V., Chuchu, T., Maziriri, E.T. \& Madinga, N.W. (2020). Examining the usage of Instagram as a source of information for young consumers when determining tourist destinations. South African Journal of Information Management, 22(1), 1-11.

Gunn, C. (1972). Vacationscape: Designing Tourist Regions. Austin: Bureau of Business Research, University of Texas.

Gursoy, D., Chi, C. G., \& Dyer, P. (2010). Locals' attitudes toward mass and alternative tourism: The case of Sunshine Coast, Australia. Journal of Travel Research, 49(3), 381394.

Gursoy, D., Jurowski, C., \& Uysal, M. (2002). Resident attitudes: A structural modeling approach. Annals of tourism research, 29(1), 79-105.

Gursoy, D., \& Rutherford, D. G. (2004). Host attitudes toward tourism: An improved structural model. Annals of tourism Research, 31(3), 495-516.

Grönroos, C. (1978). A service-orientated approach to marketing of services. European Journal of marketing, 12, 8, 588-601.

Harrison, D. (1992). Tradition, modernity and tourism in Swaziland. Tradition, modernity and tourism in Swaziland, 148-162.

Hair Jr, J. F., Black, W. C., Babin, B. J., \& Anderson, R. (2010). Multivariate Data Analysis. Chicago: Pearson.

Hosany, S., Ekinci, Y., \& Uysal, M. (2006). Destination image and destination personality: An application of branding theories to tourism places. Journal of business research, 59(5), 638-642.

Hunter, W.C. (2013). China's Chairman Mao: A visual analysis of Hunan Province online destination image. Tourism Management, 10 (34), 101-111.

Jafari, J. (1986). A Systemic View of Sociocultural Dimensions of Tourism. In President's Commission on American Outdoors, Tourism. Washington DC. 33-50.

Jurowski, C., \& Gursoy, D. (2004). Distance Effects on Residents' Attitudes toward Tourism. Annals of tourism research, 31(2), 296-312.

Kohli, A K, \& Jaworski, B J (1990). Marketing Orientation: The Construct, Research Proposition, and Managerial Implication. Journal of Marketing, 54, 1-18.

Lea, J. (1988). Tourism and development in the Third World. Methuen Introductions to Development. London: Routledge.

Lehtinen, J.R. (1983). Customer Oriented Service System. Service Management Institute, Working Paper, Helsinki, Finland.

Leisen, B. (2001). Image segmentation: the case of a tourism destination. Journal of services marketing, 15 (1), 49-66.

Line, N.D., \& Wang, Y. (2017). A multi-stakeholder market oriented approach to destination marketing. Journal of Destination Marketing \& Management, 6 (36), 84-93. 
Madden, T. J., Ellen, P. S., \& Ajzen, I. (1992). A comparison of the theory of planned behavior and the theory of reasoned action. Personality and social psychology Bulletin, 18(1), 3-9.

Malhotra, N. K. (2007). Marketing research: An applied orientation. Englewood Cliffs, New Jersey: Prentice-Hall, Inc.

Martin, J. M. (2019). Impacts of the tourist activity and citizens' evaluation about the necessity for resting periods. In Strategic perspectives in destination marketing (pp. 81112). IGI Global.

Maumbe, K., \& Van Wyk, L. (2016). Destination Cape \& Western Cape: Analysis of destination brand awareness, identity and image in the domestic market. University of Massachusetts Amherst.

Mokoena, B. A., Dhurup, M., \& Surujlal, J. (2016). A dimensional analysis of destination image variables in a South African context: an exploratory study. International Journal of Economics and Finance Studies, 8(2), 190-204.

Murphy, P., Pritchard, M. P., \& Smith, B. (2000). The destination product and its impact on traveller perceptions. Tourism management, 21(1), 43-52.

Narver, J. C., \& Slater, S. F. (1990). The effect of a market orientation on business profitability. Journal of marketing, 54(4), 20-35.

Nicholas, L. N., Thapa, B., \& Ko, Y. J. (2009). Residents' perspectives of a world heritage site: The pitons management area, st. Lucia. Annals of tourism research, 36(3), 390412.

Pan, B., \& Li, X. R. (2011). The long tail of destination image and online marketing. Annals of tourism research, 38(1), 132-152.

Park, E., \& Boo, S. (2009). An assessment of convention tourism's potential contribution to environmentally sustainable growth. Journal of Sustainable Tourism, 18(1), 95-113.

Patroni, J., Day, A., Lee, D., Chan, L., Kim, J., Kerr, D., Newson, D., \& Simpson, G. D. (2018). Looking for evidence that place of residence influenced visitor attitudes to feeding wild dolphins. Tourism and hospitality management, 24(1), 87-105.

Puczkó, L., \& Rátz, T. (2000). Tourist and resident perceptions of the physical impacts of tourism at Lake Balaton, Hungary: Issues for sustainable tourism management. Journal of Sustainable Tourism, 8(6), 458-478.

Qu, H., Kim, L. H., \& Im, H. H. (2011). A model of destination branding: Integrating the concepts of the branding and destination image. Tourism management, 32(3), 465-476.

Ramkissoon, H., \& Nunkoo, R. (2011). City image and perceived tourism impact: Evidence from Port Louis, Mauritius. International Journal of Hospitality \& Tourism Administration, 12(2), 123-143.

Rastegar, H. (2010). Tourism development and residents' attitude: a case study of Yazd, Iran. Tourismus: An International Journal of Tourism, 5(2), 203-211. 
Robben Island Museum. (2017). Some Key Issues Affecting Robben Island. Available: http://www.robbenisland.org.za/files/publications/Integrated\%20conservation\%20mana gement\%20plan/icmp_chapt10.pdf. Accessed 4/02017.

Sharma, B., \& Dyer, P. (2009). Residents' involvement in tourism and their perceptions of tourism impacts. Benchmarking: An International Journal, 16(3), 35-71.

Sheppard, B. H., Hartwick, J., \& Warshaw, P. R. (1988). The theory of reasoned action: A meta-analysis of past research with recommendations for modifications and future research. Journal of consumer research, 15(3), 325-343.

Sinclair-Maragh, G., Gursoy, D., \& Vieregge, M. (2015). Residents' perceptions toward tourism development: A factor-cluster approach. Journal of Destination Marketing \& Management, 4(1), 36-45.

Stylidis, D., Biran, A., Sit, J. \& Szivas, E.M. (2014). Residents' support for tourism development: The role of residents' place image and perceived tourism impacts. Tourism Management, 45, 260-274.

Stylos, N., Vassiliadis, C. A., Bellou, V., \& Andronikidis, A. (2016). Destination images, holistic images and personal normative beliefs: Predictors of intention to revisit a destination. Tourism Management, 53, 40-60

Tasci, A. D., \& Kozak, M. (2006). Destination brands vs destination images: Do we know what we mean?. Journal of vacation marketing, 12(4), 299-317.

Teye, V., Sirakaya, E. \& Sönmez, S.F. (2002). Residents' attitudes toward tourism development. Annals of tourism research, 29(3), 668-688.

Thomas, R. (2013). International perspectives on small firms in tourism: a synthesis. In Small firms in tourism (pp. 11-22). Routledge.

Wang, Y., \& Pfister, R. E. (2008). Residents' attitudes toward tourism and perceived personal benefits in a rural community. Journal of Travel Research, 47(1), 84-93.

Williams, J., \& Lawson, R. (2001). Community issues and resident opinions of tourism. Annals of tourism research, 28(2), 269-290.

Wolcott, H. F. (1995). Making a study 'more ethnographic'. In J. Van Maanen (Ed.), Representation in ethnography (pp. 79-111). London: Sage. 